\title{
COL7A1 Exon 73 Mutation
}

National Cancer Institute

\section{Source}

National Cancer Institute. COL7A1 Exon 73 Mutation. NCI Thesaurus. Code C162523.

A molecular genetic abnormality indicating the presence of a mutation in exon 73 of the COL7A1 gene. 